\author{
ІНФОРМАЦІЙНО-АНАЛІТИЧНЕ ЗАБЕЗПЕЧЕННЯ СИСТЕМИ \\ МОНІТОРИНГУ ЯКОСТІ ПІДВИЩЕННЯ КВАЛІФІКАЦІЇ ФАХІВЦІВ \\ ПРОФЕСІЙНОЇ (ПРОФЕСІЙНО-ТЕХНІЧНОЇ) ОСВІТИ \\ INFORMATION AND ANALYTICAL SUPPORT OF QUALITY \\ MONITORING SYSTEMS FOR PROFESSIONAL DEVELOPMENT \\ OF SPECIALISTS OF VOCATIONAL EDUCATION
}

УДК 377.3

DOI https://doi.org/10.32843/2663-

6085/2020/29-2.27

\section{Сидоренко В.В.,}

докт. пед. наук, доцент,

директор

Білоцерківського інституту

неперервної професійної освіти

ДЗВО «Університет менеджменту освіти»

\section{Денисова А.В.,}

В. о. заступника директора

з навчальної роботи

Білоцерківського інституту

неперервної професійної освіти

ДзВО «Університет менеджменту освіти»

\section{Сахно О.В.,}

канд. с.-г. наук, доцент,

завідувач кафедри технологій навчання,

охорони праці та дизайну

Білоцерківського інституту

неперервної профресійної освіти

дзВО «Університет менеджменту

освіти»

\section{Кулішов В.С.,}

канд. пед. наук,

доцент кафедри методики професійної освіти та соціально-гуманітарних дисциплін

Білоцерківського інституту неперервної профресійної освіти

ДЗВО «Університет менеджменту освіти»
У статті визначено, що в сучасних умовах розвитку знаннєвого суспільства інсрормація розглядається як важливий стратегічний ресурс, а ефективне управління інформаційними потоками є конкурентною перевагою як держави загалом, так і організацій, установ зокрема. Проведено аналіз джерельної бази дослідження щодо компонентів інфрормаційно-аналітичного забезпечення системи моніторингу якості підвищення кваліфрікації фрахівців професійноі (профресійно-технічноі) освіти. З'ясовано, що інсбормаційно-аналітичне забезпечення системи моніторингу якості підвищення квалісрікації фрахівців спрямоване: по-перше, на відстеження інорормації щодо визначених інфрормаційних потреб керівництва закладу освіти та ключових стейкхолдерів відповідно до визначених критеріїв та показників якості підвищення кваліфікації фрахівців; по-друге, на аналітико-синтетичне перетворення вхідних інфрормаційних джерел в інфрормаційні продукти (продукцію), які систематизують $і$ узагальнюють інсрормацію, містять висновки та рекомендації для розв'язання проблем прийняття обгрунтованих управлінських рішень та зниження можливих ризиків. Представлено загальну схему фрормування інфрормаційноі бази моніторингу, адаптовану до моніторингу якості підвищення кваліфрікації фахівців П(ПТ)О. Визначено систему дій щодо есрективного інсрормаційно-аналітичного забезпечення системи моніторингу якості підвищення кваліфрікації фрахівців. Отже, соціокультурні виклики вказують на необхідність упровадження $i$ використання інсрормаційно-аналітичних систем і технологій, які не лише організують доступ до актуальних, конкретних, теоретично обгрунтованих, безперервно поновлюваних даних, забезпечують організацію оперативної взаємодії усіх ланок закладу освіти, а й сприяють консолідації зусиль експертів, методистів, науковців, програмістів у напрямі реалізації гнучкої, адаптивної системи моніторингу якості в закладах ППО. Ключові слова: якість освіти, система моніторингу якості, підвищення кваліфрікаціі, моніторингові дослідження, інформаційно- аналітичне забезпечення, інфрормаційноаналітична система.

This article defines that in the current conditions of knowledge society development information is considered as an important strategic resource, and effective management of information flows is a competitive advantage of the state as a whole and organizations, institutions in particular. The analysis of the source base of the study on the components of information and analytical support of the system for monitoring the quality of advanced training of specialists (vocational) education is carried out. It was found that the information and analytical support of the system of monitoring the quality of professional development are aimed at: first, to track information on the identified information needs of the management of the educational institution and key stakeholders under certain criteria and indicators of professional development; secondly, the analytical and synthetic transformation of input information sources into information products (products), which systematize and summarize information, contain conclusions and recommendations for solving problems of making sound management decisions and reducing possible risks. The general scheme of formation of the information base of monitoring adapted to the monitoring of the quality of professional development of specialists of professionals (vocational) education, is presented. The system of actions concerning effective informationanalytical providing of the system of monitoring of the quality of advanced training of experts is defined. Thus, sociocultural challenges indicate the need for the introduction and use of information-analytical systems and technologies that not only organize access to relevant, specific, theoretically sound, continuously updated data, ensure the organization of operational interaction of all parts of the institution, but also consolidate the efforts of experts. methodologists, scientists, programmers in the direction of implementing a flexible, adaptive quality monitoring system in air defense facilities.

Key words: quality of education, quality monitoring system, advanced training, monitoring research, information-analytical support, information-analytical system.
Постановка проблеми в загальному вигляді. У сучасних умовах розвитку знаннєвого суспільства інсрормація розглядається якважливий стратегічний ресурс, а ефрективне управління інформаційними потоками $€$ конкурентною перевагою як держави загалом, так і організацій, установ зокрема. Бурх- ливий розвиток інфрормаційних процесів в освітній галузі передбачає створення, широке впровадження, використання інформаційних систем i технологій, актуалізує потребу продуктивного використання сучасних інфоормаційно-аналітичних технологій в управлінській діяльності закладів освіти. 
Осмислення специфіки інформаційно-аналітичних технологій як інструмента якісно-змістового перетворення первинної інорормації в оптимальне управлінське рішення фрормулює актуальність і значущість проблеми інформаційно-аналітичного забезпечення управлінських процесів закладу освіти, зокрема моніторингу якості. Результатом цього осмислення стає пошук комплексних рішень, які дають змогу націлити ресурси системи моніторингу якості на підтримку та прогностичну оцінку управлінських рішень, забезпечення якості освіти та освітньої діяльності, зокрема в умовах модернізації профресійної (профресійно-технічної) освіти.

Аналіз останніх досліджень і публікацій. Аналізована в нашому дослідженні проблема спонукає науковців до активних пошуків і дискусій щодо питань фрормування й розвитку цифрової компетентності та практичних аспектів впровадження цифрових технологій у вітчизняній освіті. Так, питанням створення середовища розвитку ІКТ-компетентності суб'єктів освітнього процесу, проведення педагогічних досліджень з інформатизації освіти присвячено праці вітчизняних дослідників, зокрема В. Бикова, А. Гуржія, В. Дем'яненка, Л. Карташової, В. Кухаренка, В. Лапінського, Н. Морзе, В. Олійника, О. Спіріна, Ю. Тріуса та ін. Проєктування автоматизованих систем моніторингу якості освіти на рівні закладів освіти здійснено О. Білик, Т. Коротун, О. Слабоспицькою, Г. Коваль, О. Туржанською та ін. Н. Височиною, Л. Шумовою, В Міняйло, О. Середіною представлено архітектурне рішення єдиної автоматизованої регіональної інфрормаційної системи моніторингу якості освіти. Модель фрункціонування інформаційно-аналітичної системи багаторівневого моніторингу якості освіти розроблена В. Чекуріним, С. Острей, О. Острей. ІТ-компоненти моніторингу якості освітнього процесу розглядаються М. Сільченко, В. Горбовим, Ю. Горбовою, І. Денковичем. Проєктування інорормаційних систем моніторингу процесу підвищення кваліфрікації педагогічних працівників представлено в роботах П. Грабовського, 3. Рябової, Л. Покроєвої та ін.

Виділення не вирішених раніше частин загальної проблеми. Незважаючи на значний доробок вітчизняних учених, проблема адаптації й впровадження інфрормаційно-аналітичних систем технологій моніторингу якості підвищення кваліфікації фрахівців у галузі П(ПТ)О не стала предметом ґрунтовного вивчення й узагальнення. Зокрема неповною мірою розв'язано проблеми прикладних рішень у впровадженні інформаційно-аналітичних систем і технологій моніторингу якості підвищення кваліфрікації фрахівців у галузі П(ПТ)О, організації підсистеми інорормаційно-аналітичного забезпечення системи моніторингу якості підвищення кваліфікації фрахівців, недостатньо стандартизовано моніторингові процедури з ідентифрікації інформа- ційних потреб керівників закладів освіти, замовників (споживачів) освітніх послуг та соціальних партнерів, проблеми фрормалізації оцінки якості освітньої діяльності тощо.

Мета статті полягає у ґрунтовному аналізі інформаційно-аналітичного забезпечення системи моніторингу якості підвищення кваліфрікації фрахівців професійної (професійно-технічної) освіти, визначенні його компонентного складу й змістового наповнення.

Виклад основного матеріалу. Розтлумачимо основні дефініції дослідження та розмежуємо поняття «інорормаційно-аналітичне забезпечення (IA3)», «інорормаційно-аналітична діяльність (ІАД)», «інфрормаційно-аналітична технологія» (IAT), «інфрормаційно-аналітична система (IAC)» для запобігання термінологічної плутанини та, як наслідок, викривлення сутності понять у застосуванні в площині моніторингу якості.

Загальний термін «інформаційні технології» використовується для посилань на всі технології, пов'язані зі створенням, обробкою, зберіганням, використанням, пересиланням та керуванням інформацією. Інформаційні технології (IT, інформаційно-комунікаційні технології) - процеси, в яких основною продукцією, що переробляється, $є$ інфрормація [1]. Еволюційні процеси в інорормаційних технологіях призвели до того, що первинний аналіз даних перекладено на обчислювальну техніку, отже, нині під інформаційними технологіями найчастіше розуміють комп'ютерні технології. Інформаційна технологія тісно пов'язана 3 інформаційними системами, тобто її основним середовищем. Своєю чергою необхідними засобами для здійснення всіх операцій $з$ інформацією (проведення будь-яких видів інфрормаційної взаємодії), що створюють інфрормаційну інорраструктуру, є інформаційні ресурси (банки та бази даних), інформаційні системи (системи доступу до даних), а також інфрормаційні технології (програмне забезпечення комп'ютерів, комунікативні мережі) [2].

Беззаперечно, інформаційні системи і технології (ICT) спрямовані на підвищення ефективності та вдосконалення різних галузей діяльності людини.

Профресор Є. Хриков [3, с. 194], досліджуючи питання інформатизації закладу освіти, зазначає, що інфрормаційні технології дають змогу підвищити ефрективність усіх складників процесу розробки та реалізації управлінського рішення: отримання необхідної інфрормації, розробка управлінського рішення, доведення управлінського рішення до виконавців, контроль за виконанням управлінського рішення. Ним виділено та обґрунтовано і ширшу фрункцію інорорматизації закладу освіти, яка полягає в отриманні, фріксації, зберіганні та перетворенні інформації. Саме ця функція створює умови для реалізації ще однієї важливої функ- 
ції інформатизації закладу освіти - задоволення інорормаційних потреб здобувачів освіти, працівників, потенційних споживачів освітніх послуг, працівників інших освітніх установ та структур управління освітою.

Система інфрормаційно-аналітичних заходів спрямована на задоволення інформаційних потреб користувачів інформації шляхом ії підготовки та доведення до споживачів $€$ інорормаційно-аналітичне забезпечення [4, с. 54].

С. Телешун, І. Рейтерович [5, с. 5] визначають систему інформаційного-аналітичного забезпечення управління як взаємозалежну та відповідним чином сорормовану сукупність організаційних, організаційно-правових, інформаційних, методичних, програмно-технологічних компонентів, що забезпечує необхідну якість прийнятих управлінських рішень шляхом раціонального використання інсрормаційних ресурсів та інформаційних технологій.

Дослідник інфрормаційної інфраструктури В. Степанов [6] вибудовує такий ланцюг її складників: інфрормаційно-аналітична діяльність $\epsilon$ складником інформаційно-аналітичного забезпечення; інформаційно-аналітичне забезпечення, що забезпечує єдність і взаємозв'язок процесів виробництва, пошуку, збереження, обміну, поширення й споживання інфрормації, - складник інформаційної інфрраструктури.

О. Яценко [7, с. 12] досліджує інформаційноаналітичну діяльність у двох контекстах: перший це погляд на інфрормаційну аналітику як на один із напрямів консалтингової діяльності («консалтинговий підхід»); другий ґрунтується на розгляді інсрормаційно-аналітичної діяльності як складника інформаційної. Дослідник визначає, що інструментальною частиною інфрормаційної аналітики $€$ інфрормаційні технології.

Своєю чергою Ю. Сурмін та Н. Туленков [8, с. 276] розглядають інфрормаційно-аналітичну діяльність та технології її реалізації в єдності та пропонують універсальну модель технології аналітичної діяльності, яка включає такі етапи: визначення предмета, об'єкта та проблеми аналізу; побудова ідеальної моделі об'єкта та предмета аналізу; побудова гіпотез; вибір типу й виду аналізу; вибір або розробка методів аналізу; доказ гіпотез; формулювання аналітичних висновків та розробка рекомендацій.

Отже, інформаційно-аналітична діяльність - це: 1) сукупність дій на основі концепцій, методів, засобів, нормативно-методичних матеріалів для збору, накопичення, обробки та аналізу даних із метою обґрунтування та прийняття рішень [9, с. 16-17]; 2) це особливий напрям інфрормаційної діяльності, сукупність дій та заходів, пов'язаних із виявленням, опрацюванням, збереженням інформації 3 проблемних ситуацій у базовій діяльності користувачів (чи проблемних питань галузі загалом), що потребують вирішення, утворення на її основі оглядово-аналітичних документів, їх поширення на засадах інорормаційних технологій [10, с. 7]

І. Савченко, В. Ягупов [4, с. 81], досліджуючи інфрормаційно-аналітичну діяльність, виділяють відповідні рівні (напрями) інформаційно-аналітичної роботи: 1) інформаційний рівень, що полягає в пошуку, збиранні, зберіганні, поширенні інорормації; 2) аналітичний рівень, що передбачає узагальнення, класифікацію інформації, її аналіз і перетворення, розроблення висновків, пропозицій, рекомендацій і прогнозів. Однією з форм інформаційно-аналітичної роботи, на їхню думку, виступає моніторинг.

Оптимізація інформаційно-аналітичної діяльності закладу освіти можлива за умови побудови відповідних інфрормаційно-аналітичних систем. Зокрема, С. Карплюк, Т. Вакалюк [11] вважають, що шляхом забезпечення якісного менеджменту в сучасному інфрормаційно орієнтованому виші $€$ впровадження й активне використання інформаційно-аналітичних Web-орієнтованих систем.

О. Нестеренко [12, с. 55] визначає інорормаційно-аналітичні системи як суспільні структури, що містять інформаційні технології, інфрормаційні системи й інформаційні ресурси для забезпечення здійснення інфрормаційно-аналітичної діяльності.

У найбільш загальному вигляді інфрормаційноаналітична система (IAC) [13] - це комп'ютерна система, яка, окрім отримання даних, їх створення та опрацювання, дає змогу виконувати аналіз даних. IAC забезпечує для установи (організації) єдиний інорормаційний простір і гарантує, що ці дані будуть доступні на всіх фрункціональних рівнях ієрархії та управління. І. Захарова та л. Філіпова акцентують на специоріці цього класу інфрормаційних систем як систем для аналітичної обробки даних, а не для автоматизації повсякденної діяльності організації.

Ми поділяємо думку вчених, які зараховують системи моніторингу до класу інформмаційно-аналітичних систем підтримки управлінських рішень.

В. Галіцин [14] фрормулює таке визначення системи моніторингу: це інорормаційно-аналітична система спостереження за об'єктом шляхом збирання, систематизації, оброблення та нагромадження інформації з метою аналізу та оцінювання його поточного стану відповідно до заздалегідь розробленої програми, діагностики й оцінювання його очікуваного стану на певний момент у разі порушення рівноваги і тенденцій розвитку внаслідок можливих впливів внутрішнього або зовнішнього середовища та формування інформаційно-аналітичної бази для прийняття управлінських рішень щодо забезпечення цілей розвитку об'єкта. 
I. Аннєнкова [15, с. 393] визначає моніторинг якості як інфрормаційно-аналітичну систему, що постійно оновлюється на основі безперервного (циклічного) відстеження стану і динаміки змін якості з метою прогнозування її подальшого розвитку, вироблення ефективних управлінських рішень та постійного покращення якості.

І. Захарова, Л. Філіпова [16, с. 59] зазначають, що моніторингові дослідження призначені для довготермінового аналітичного спостереження за розвитком певної ситуації з метою забезпечення можливості апріорного синтезу управлінських рішень, які мають профілактичний або застережний характер. Інфрормаційно-аналітичний моніторинг тлумачать як вид інфрормаційної діяльності, пов'язаний із процесами аналізу, синтезу інорормації із застосуванням методів моделювання, експертного оцінювання, діагностики і прогнозування, що реалізуються в режимах постійного збирання інфрормації $з$ традиційних і нетрадиційних джерел із метою регулярного інформаційного забезпечення користувачів.

Отже, розгляд науковцями терміна «інфрормаційно-аналітичне» як складного прикметника призводить до визначення його ролі у звуженні значення слова «забезпечення» до рівня конкретної сорери застосування (у нашому дослідженні моніторингу якості), а саме:

- інфрормаційної - порівняно самостійної діяльності спеціально підготовлених фахівців, зайнятих пошуком, відбором, обробкою, накопиченням, узагальненням і збереженням інформаційних одиниць (перший етап процесу інфрормаційно-аналітичного забезпечення у системі управління будьякого механізму);

- аналітичної - як похідний другий етап процесу інформаційно-аналітичного забезпечення у системі управління будь-якого механізму: виробництво спеціально підготовленими фахівцями на підставі наявних інформаційних одиниць і складних розумових процесів нового знання щодо явища або події, що вивчається [17].

Слушною в аспекті дослідження інформаційноаналітичної системи моніторингу якості підвищення кваліфікації фрахівців є заувага О. Мітіна та Т. Філічевої [18, с. 49], що відмінною особливістю IAC моніторингу якості $€$ орієнтованість на рішення експертно-аналітичних завдань оцінки поточного стану якості освітніх послуг та фрормування рекомендацій для особи, яка приймає рішення (ОПР) про підвищення якості.

Усвідомлюючи експоненціальний характер зростання масивів інформації та інтенсивності інорормаційних потоків в усіх галузях знань, висхідний рух інформаційних систем та технологій (ICT), розвиток цифрової компетентності працівників освітньої галузі, учені, зокрема О. Білик, П. Грабовський, В. Галіцин, О. Севрук та ін., обґрун- товують доцільність їх впровадження у процес моніторингу для автоматизації рутинних операцій щодо опрацювання отриманих, поширення даних, застосування програмних засобів для їх візуалізації та аналізу тощо.

Зупинімося докладніше на складниках інформаційно-аналітичного забезпечення системи моніторингу якості підвищення кваліфікації фрахівців.

На думку дослідників $€$. Масленнікова, О. Побережець [19], інфрормаційний складник інфрормаційно-аналітичного забезпечення фрормується з урахуванням планової, облікової, нормативно-правової та звітно-статистичної інорормації. В. Галіцин [14] до джерел первинної інформації зараховує статистичну звітність, анкетування, інтерв'ю, опитування, дані наукових досліджень, мережі Інтернет тощо.

У процесі аналізу інсрормації в сучасних умовах використовують такі групи показників: якісні характеристики, що включають достовірність, релевантність, пертинентність, адекватність (об'єктивність) інфрормації; кількісні характеристики, що передбачають достатність (повноту), точність інфрормації; ціннісні характеристики (своєчасність, актуальність інорормації) [20, с. 28].

Інформаційне забезпечення уможливлює інтегровану обробку інорормації, яка циркулює в організації (установі) й оцінку стану показників, які характеризують результативність та ефективність діяльності, з іншого боку - для фрормування аналітичного складника інфрормаційно-аналітичного забезпечення системи управління використовують інфрормаційну та нормативно-правову базу, яка забезпечує процес управління необхідними відомостями щодо стану суб'єкта для проведення аналізу результатів діяльності.

Загальну схему фрормування інформаційної бази моніторингу (за В. Галіциним), адаптовану до моніторингу якості підвищення кваліфікації фрахівців П(ПТ)О, наведено на рис. 1.

У схемі, по-перше, визначено критерії (якості організації освітнього середовища, процесуальний критерій та результативності освітньої діяльності) та відповідні показники, які у своїй сукупності розкривають цілісність оцінки якості підвищення кваліфрікації фрахівців у галузі П(ПТ)О, окремо - аспекти якості освітньої діяльності. По-друге, основними джерелами інфрормації для забезпечення системи моніторингу якості підвищення кваліфрікації фрахівців у галузі профресійної освіти є такі:

- правова інформація (законодавчі і підзаконні нормативно-правові акти, масиви локальних нормативних актів закладу освіти, а також ненормативні правові акти, повідомлення засобів масової інфрормації, публічні виступи, інші джерела інформації з правових питань);

- статистичні дані (деперсоналізована інформація про здобувачів освіти, показники, що 
відображають рівень забезпечення необхідних ресурсів (нормативних, навчальних і методичних) для організації освітнього процесу, рівень використання інформаційних систем для ефективного управління освітнім процесом та ін.);

- планова і звітно-статистична інформація щодо контингенту слухачів, рівня досягнень освітніх результатів на курсах підвищення кваліфрікації (в тому числі, дані спостережень за освітнім процесом та освітньою діяльністю в закладах освіти, опитування, тестування), експертна інформація тощо.

По-третє, планову періодичність збору інорормації (щомісяця, щокварталу, кожного півріччя, щороку та ін.) або збір інорормації позапланово самостійно визначає розпорядник інформації.

По-четверте, зібрана первинна інформація має бути систематизована, впорядкована, представлена консолідацією або класифікацією варіантів відповідей та відображена у зручній для аналізу формі (табличній, візуальній тощо).

Процес формування інформаційної бази моніторингу якості підвищення кваліфрікації фрахівців П(ПТ)О повинен мати безперервний, циклічний (спрямовуватися на постійне поповнення інформаційної бази відповідними кількісно-якісними показниками), адаптивний (змінний як за кількістю, так і за складом показників відповідно до коригування мети й індикаторів стратегії об'єкта) характер та органічно вписуватися в систему інформаційного забезпечення діяльності закладу освіти.

Формування підсистеми аналітичного забезпечення здійснюється на основі аксіологічного, атрибутивного, івент-аналізу, контент-аналізу, праксеологічного, проблемного, системного, ситуаційного, стратегічного, операційного, SWOT-аналізу тощо.

Аналітичне та статистичне оброблення структурованої первинної інфрормації, як зазначає В. Галіцин [14], має за мету якомога точніше, якісне та своєчасне відображення процесів, що протікають в аналізованій предметній царині, а також виявлення їхніх характерних тенденцій.

3 точки зору користувача моніторингові задачі за своїм призначенням поділяються на регламентні задачі, пов'язані з обробленням даних статистичної звітності, задачі інформаційно-довідкового обслуговування, задачі поглибленого аналізу.

Кожна регламентна задача, як правило, пов'язана з обробленням даних деякої конкретної фрорми статистичної звітності або кількох, тісно пов'язаних за змістом фрорм звітності.

Задачі інфрормаційно-довідкового обслуговування передбачають фрормування за запитами необхідних статистичних даних для оперативного складання доповідей, аналітичних записок і довідок, не регламентованих за змістом. Їх вирішення забезпечується за допомогою автоматизованого банку даних у вигляді системи нагромадження, збереження, пошуку, оброблення та видачі інорормації за запитами користувачів у потрібному вигляді.

Задачі поглибленого аналізу передбачають використання динамічних рядів, фракторного аналізу, кореляційного аналізу (отримання кореляційних матриць, середніх і стандартних відхилень).

Таким чином, аналітичний складник інформаційно-аналітичного забезпечення системи моніторингу якості підвищення кваліфікації фрахівців у галузі професійної (професійно-технічної) освіти включає: інтегральні показники якості освітньої діяльності на курсах підвищення кваліфікації (по роках); кількісно-якісний порівняльний аналіз показників рівня задоволеності замовників (споживачів) освітніх послуг та його складників; діагностику обліку успішності слухачів курсів підвищення кваліфрікації в навчальних групах, системи експертного оцінювання показників якості тощо. Своєю чергою аналіз здійснюється на основі відхилень розрахункових показників від нормативних (еталонних) показників якості підвищення кваліфікації фрахівців:
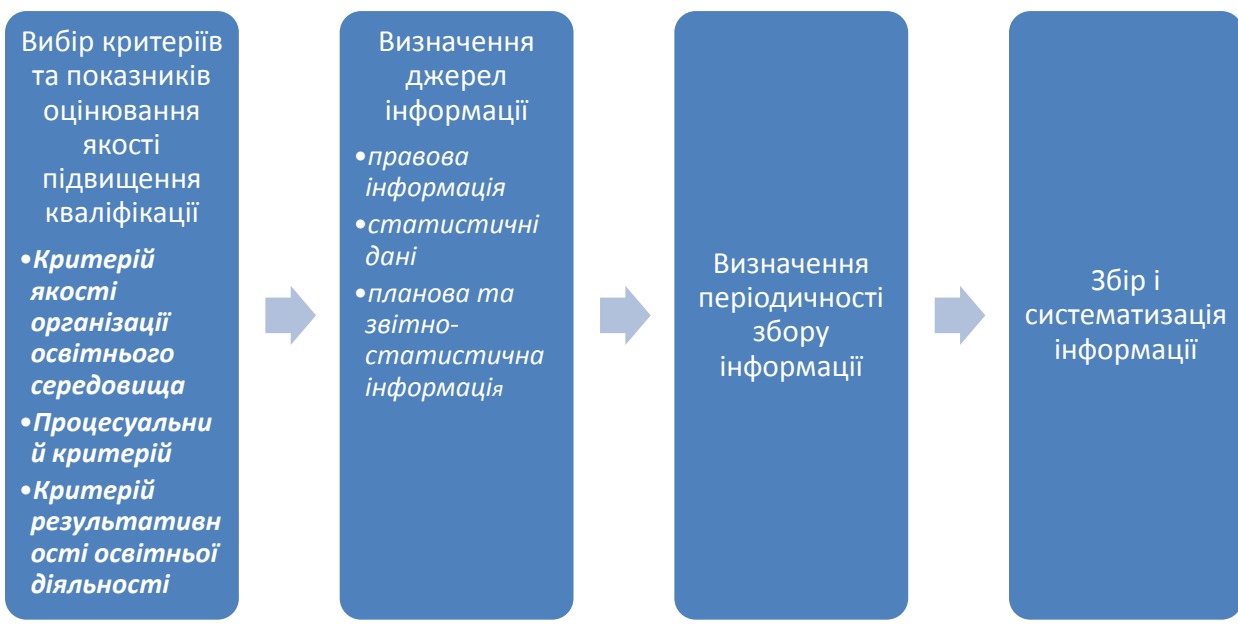

Рис. 1. Схема фоормування інформаційної бази моніторингу якості підвищення кваліфікації фрахівців П(ПТ)О 


$$
\sum_{i=1}^{n} \alpha_{l}\left|x_{i}-x_{i}^{e x p}\right| \rightarrow \min ,
$$

де $x_{i}$ - реальний показник; $x_{i}^{\mathrm{exp}}-$ еталонний (експертний) показник.

Означені показники та пропозиції знаходять відображення у фрормах статистичної звітності, аналітичних довідках, експертних висновках, звітах щодо оцінки підвищення кваліфікації слухачів, якості освітніх послуг.

Отже, ефрективне інсрормаційно-аналітичне забезпечення системи моніторингу якості підвищення квалісрікації фрахівців передбачає реалізацію такої системи дій:

1) удосконалення і розвиток систем автоматизованого документообігу, спрямованих на реалізацію широкого спектра дій щодо реєстрації, забезпечення зберігання і сортування даних, взаємодію відповідних структурних підрозділів під час вирішення завдань моніторингу та прийняття відповідних управлінських рішень;

2) забезпечення надійності і захисту від несанкціонованого доступу до інформації;

3) упровадження програмного забезпечення, здатного забезпечувати зручний інтерфейс користувача; створювати банк даних; розраховувати в автоматичному режимі показники якості підвищення кваліфікації замовників освітніх послуг; надавати узагальнену інорормацію про динаміку освітнього процесу, рівень досягнень результатів навчання на курсах підвищення кваліфікації, ступеня задоволеності запитів і потреб слухачів, відповідності змісту навчання їхнім професійним потребам та фрормувати відповідні звіти;

4) підвищення кваліфікації фрахівців-аналітиків та підготовка педагогічних працівників для здійснення і проведення моніторингу.

Висновки. Соціокультурні виклики вказують на необхідність упровадження і використання інсоормаційно-аналітичних систем і технологій, які не лише організують доступ до актуальних, конкретних, теоретично обґрунтованих, безперервно поновлюваних даних, забезпечують організацію оперативної взаємодії усіх ланок закладу освіти, а й сприяють консолідації зусиль експертів, методистів, науковців, програмістів у напрямі реалізації гнучкої, адаптивної системи моніторингу якості в закладах ППО. Водночас інформаційно-аналітичне забезпечення системи моніторингу якості підвищення кваліфікації фрахівців спрямоване, по-перше, на відстеження інфрормації щодо визначених інформаційних потреб керівництва закладу освіти та ключових стейкхолдерів відповідно до визначених критеріїв та показників якості підвищення кваліфрікації фахівців, по-друге, на аналітико-синтетичне перетворення вхідних інформаційних джерел в інорормаційні продукти (продукцію), які систематизують і узагальнюють інсрормацію, містять висновки та рекомендації для розв'язання проблем прийняття обґрунтованих управлінських рішень та зниження можливих ризиків.

\section{БІБЛІОГРАФІЧНИЙ СПИСОК:}

1. Тлумачний словник з інфрорматики / Г.Г. Півняк, Б.С. Бусигін, М.М. Дівізінюк та ін. Дніпропетровськ : Нац. гірнич. ун-т, 2010. 600 с.

2. Карпенко О. Понятійно-категоріальний апарат науки державного управління у сфрері інформаційно-аналітичного забезпечення діяльності органів виконавчої влади. Державне управління та місцеве самоврядування. 2009. Вип. 2(2).

3. Хриков Є.М. Управління навчальним закладом : навч. посібник. Киї в: Знання, 2006. 365 с.

4. Ягупов В.В. Інсрормаційно-аналітична діяльність педагогічних працівників професійно-технічних навчальних закладів: термінологічний словник / І.М. Савченко, В.В. Ягупов. Київ : ІПТО НАПН України, 2014. 127 с.

5. Телешун С.О. Інфрормаційно-аналітична діяльність в державному управлінні : навч.-метод. матеріали. Київ : НАДУ, 2013. 36 с.

6. Степанов В. Інфрормаційно-аналітичне забезпечення системи державного управління. Теорія та практика державного управління і місцевого самоврядування. 2015. № 1.

7. Яценко О.М. Науково-педагогічна бібліотека України імені В.О. Сухомлинського у становленні системи інфрормаційно-аналітичного забезпечення педагогічної науки, освіти і практики України. Наукові праці Державної науково-педагогічної бібліотеки України імені В.О. Сухомлинського. 2012. Вип. 3. С. 21-41.

8. СурминЮ.П., ТуленковН.В.Теориясоциальных технологий : Учеб. пособие. Київ : МАУП, 2004. 608 с.

9. Варенко В.М. Інформаційно-аналітична діяльність : навч. посібник. Київ : Університет «Україна», 2014. 417 c.

10.Концептуальна модель системи інфрормаційно-аналітичного забезпечення педагогічної науки, освіти і практики України / НАПН України. Держ. наук.пед. б-ка України ім. В.О. Сухомлинського [уклад. О.М. Яценко; наук. ред. П.І. Рогова ; рец.: ЮІ. Артемов, Т. Ф. Букшина ; літ. ред.: С.М. Зозуля, І.П. Білоцерківець]. Київ : Інститут обдарованої дитини НАПН України, 2010. 28 с.

11. Карплюк С. Огляд фрункціональних можливостей програмного забезпечення для управління освітнім процесом закладу вищої освіти / С. Карплюк, Т. Вакалюк. Інфрормаційні технології і засоби навчання. 2018. Том 65. № 3.

12. Нестеренко О.В. Основи побудови інформаційно-аналітичних систем органів державної влади. Київ : Наук. думка, 2005. 628 с.

13.Додонов А.Г. Компьютерные инорормационно-аналитические системы и хранилища данных: толковый словарь / А.Г. Додонов, Д.В. Ландэ, С.Р. Коженевский, В.Г. Путятин. Киев: Феникс; ИПРИ НАН Украины, 2013. 554 с.

14. Галіцин В.К. Системи моніторингу : навч. посібник / В.К. Галіцин, О.П. Суслов, Н.К. Самченко. Київ : KHEУ, 2015. 408 c.

15. Аннєнкова І.П. Теорія і методика моніторингу якості професійної діяльності науково-педагогічних 
працівників вищих навчальних закладів : дис. ... докт. пед. наук : 13.00.06. Київ, 2016. 517 с.

16. Захарова І.В. Основи інфрормаційно-аналітичної діяльності: навч. посібник / І.В. Захарова, Л.Я. Філіпова. Київ : Центр учбової літератури, 2013. 335 с. 3 дар. написом авт. ISBN 978-617-673-175-7

17. Соціально-правові основи інфрормаційної безпеки : навч. посібник / В.М. Петрик, А.М. Кузьменко, В.В. Остроухов та ін.; за ред. В.В. Остроухова. Київ : Росава, 2007. 496 с.

18. Митин А.И., Филичева Т.А. Инорормационно-аналитическая система мониторинга каче- ства профессиональной подготовки. Открытое образование. 2013. № 4(99). С. 46-51. URL: https://doi.org/10.21686/1818-4243-2013-4(99)-46-51.

19. Масленніков Є.I. Інфрормаційно-аналітичне забезпечення системи управління результатами діяльності підприємства / Є.І. Масленніков, О.В. Побережець. Ринкова економіка: сучасна теорія і практика управління. 2016. Том 15. Вип. 1 (32).

20. Матвієнко О.В. Інформаційний менеджмент: опорний конспект лекцій у схемах і таблицях / О.В. Матвієнко, М.Н. Цивін. Київ : Університет економіки та права «КРОК», 2007. 173 с. 